\title{
USING MATLAB PACKAGE TO SOLVE INDIRECT MEASUREMENT EQUATIONS
}

\author{
ВИКОРИСТАННЯ ПАКЕТУ MАTLAВ \\ ДЛЯ ВИРІШЕННЯ РІВНЯНЬ НЕПРЯМИХ ВИМІРЮВАНЬ
}

\begin{abstract}
The article deals with the problem of mathematical training of students of pedagogical higher education, in particular the question of existing approaches to solving equations of indirect measurements. It is revealed that in Ukraine there is a need for rapid resolution of specific professional tasks using a certain set of information and communication technologies; modern social demand for the professional training of a teacher, in particular a mathematics teacher who has a thorough professional knowledge and has ICT, carries out his professional activity.

A brief description of existing practical methods for solving nonlinear equations was performed, metrological support of iterative methods for solving nonlinear equations with inaccurate initial data was performed, modeling of the behavior of iterative methods at different values of the initial data and their errors were performed. Programs have been developed that implement the considered methods of root search, which allow to solve metrologically justified nonlinear equations of indirect measurements by means of the Matlab package. Many physical quantities cannot be measured directly. In such situation, they use indirect measurements: they measure what can be measured directly, and then indirectly calculate the value of the desired value using known laws and relationships. The task is carried out in the computing unit of the measuring system that implements indirect measurement, and must also be subject to metrological control. In such situation, it looks promising and relevant to supplement the procedure for solving the equation with inaccurate data with a subroutine for estimating the error of its results. Such systems are known and have spread in certain areas of mathematics. Their use in metrology is currently limited due to the weak accounting of metrological specifics with existing approaches to working with inaccurate data.

Key words: higher education, professional training, future mathematics teachers, ICT, Matlab.
\end{abstract}

У статті розглянуто проблему математичної підготовки студентів педагогічного вишу, зокрема питання наявних підходів до рішення рівнянь непрямих вимірювань. Виявлено, що в Україніє: необхідність швидкого розв'язування специярічних професійних завдань із використанням певного набору інфрормаційно-комунікаційних технологій; сучасний соціальний запит на професійну підготовку вчителя, зокрема вчителя математики, який має ґрунтовні фрахові знання та володіє IKT, здійснює свою профессійну діяльність.

Виконано короткий опис практичних методів вирішення нелінійних рівнянь, здійснено метрологічний супровід ітераційних методів вирішення нелінійних рівнянь із неточними вихідними даними, виконано моделювання поведінки ітераційних методів при різних значеннях вихідних даних і їх похибки. Розроблено програми, що реалізують розглянуті методи пошуку коренів, які дають змогу метрологічно обґрунтовано вирішувати нелінійні рівняння непрямих вимірювань засобами пакету Matlab. Багато фрізичних величин не можуть бути виміряні безпосередньо. У такій ситуації вдаються до непрямих вимірів: вимірюють те, що може бути виміряно безпосередньо, потім вимірюють за відомими закономірностями і зв'язками, обчислюють похибку значення кінцевої величини. Виконання завдання здійснюється в обчислювальному блоці вимірювальної системи, що реалізує непряме вимірювання і також має бути піддане метрологічного контролю. У такій ситуації перспективним і актуальним видається доповнення самої процедури вирішення рівняння 3 неточними даними підпрограмою оцінки похибки ї результатів. Такі системи відомі і мають поширення в певних областях математики. Застосування їх у метрології нині обмежене через слабкий облік метрологічної специяріки підходами роботи з неточними даними.

Ключові слова: вища освіта, професійна підготовка, майбутні вчителі математики, IKT, Matlab.
Raising of the problem and its copulas with important practical tasks. The calls of modern rate of life testify to entering into the phase of informative society. Such society is characterized by various information sources and information itself. Realities of present time confirm that formation of the system of knowledge is not enough for successful professional and social realization of personality. Necessary information can be quickly found but ability to decide specific professional tasks needs to be formed. Dynamic development of ICT stipulated a social request for modernization of higher pedagogical education, the aim of which is training of a teacher, in particular teacher of mathematics who has thorough professional knowledge and knowledge of ICT, carries out the professional activity, deeply realizing his pedagogical duty and social responsibility [1-2].
Many government programs and projects are dedicated to the problems of introduction of information technologies in the sphere of education. So, Laws of Ukraine "About Education" (2017), "About Higher Education" (2018), "National Strategy of Development of Education in Ukraine on a Period to 2021" (2013), "Strategy of Development of Informative Society in Ukraine" (2013), Conception of "New Ukrainian school" (2016) aimed at ensuring the conditions for effective use of modern computer technologies and improving the educational process in all educational institutions, including in higher pedagogical educational institutions.

Analysis of basic research and publications. Problems of mathematics teacher training were analyzed in the scientific works of M. Zhaldak, M. Kovtonyuk, A. Kolmogorov, M. Protsovyty, 
Yu. Trius, O. Chashechnikova and others. Scientists V. Bykov, L. Gryzun, M. Dushlyak, M. Zhaldak, N. Morse, Y. Ramsky, O. Semenikhina, S. Semerikov, and others investigate the problems of introducing ICT into the educational process of training future teachers of mathematics.

Consider using the Matlab package to solve the indirect measurement equations. Many physical quantities cannot be measured directly. In this situation, indirect measurements are resorted to: they measure what can be measured directly, and then, by known patterns and relationships, indirectly calculate the value of the desired value. From a mathematical point of view, this problem is reduced to solving an equation or system of equations with inaccurate data. Its implementation is carried out in the computing unit of the measuring system that implements indirect measurement, and must also be subject to metrological control. It is difficult to validate the procedure of solving equations: many variants of input data (the results of direct measurements coming from the measuring channels of the system) cannot be overridden when validated in any way; it is difficult to organize a sample solution of the equations to evaluate the accuracy of the obtained solutions, etc.

In such situation, it seems promising and relevant to supplement the procedure for solving the equation with inaccurate data by a subprogram for estimating the error of its results. Such systems are known and are widespread in certain areas of mathematics. Their use in metrology is currently limited due to the poor accounting of metrological specifics with existing approaches to work with inaccurate data.

The purpose of this work is to develop techniques for solving the equations of indirect measurements, justified from a metrological point of view.

Presenting main material. For this purpose it is necessary to supplement the iterative methods of solving equations known from computational mathematics in such a way that the obtained estimate of the root would be accompanied by an estimate of its error caused by the inaccuracy of the coefficients of the equation (direct measurements). In this case, the error estimates will be obtained simultaneously with the solution of the equation for any set of raw data. There are reasons to believe that estimating the error in the process of solving equations will allow to terminate the iterative procedure reasonably in agreement with the accuracy of the initial data, which can lead to a gain at run time.

Review of existing methods for solving nonlinear equations in metrological problems. In practice, various iterative methods (i.e., sequential approximation methods) are used to find the root of the nonlinear equation $f(x)=0$. To find a root using them, you must first specify the approximate root value (initial approximation) or the segment with the guarantee containing the root, and then make a consistent refinement of the approximate value to a given accuracy. As a rule, the properties of these methods are evaluated from the standpoint of computational mathematics: they consider the speed of convergence of methods, the computational complexities inherent to them, etc. In this case, usually the properties of the transformation of the error of the original data are not used in the consideration and rational choice of the method of solving the equations. Below is a brief summary of the properties of popular solution methods traditionally attributed to them.

One of the most common methods of finding the roots of the equations in the measurement problems is the Newton method and its modification (the Newton-Rafson method, the secant method) [3-5]. Of great importance when comparing the effectiveness of different methods is the speed of convergence of the iterative process to the root of the equation. The higher it is, the faster the solution of the equation can be obtained and, consequently, the result of indirect measurement. The absolute errors of the estimates of the root obtained during the iterative process on two successive iterations are related to each other as follows [5]: $\left|\boldsymbol{x}_{\boldsymbol{k}+1}-\boldsymbol{x}^{*}\right| \leq \boldsymbol{C}\left|\boldsymbol{x}_{\boldsymbol{k}}-\boldsymbol{x}^{*}\right|^{\boldsymbol{a}}$, where $C$ is a constant (depending on the solved equation, on the method of solution, on the initial approximation, etc.), $x^{*}$ is the exact root of the equation, $x_{k}-k$ is the approximation of the root (obtained in the $k$ step), $\alpha$ is the exponent that characterizes the rate of convergence (its large values provide fast convergence). When choosing an initial approximation in the vicinity of the root, the Newton method provides a quadratic convergence $(\alpha=2)$, which is a higher velocity than other methods, and that actually explains its popularity in practical use. The Newton method requires an initial root approximation. Typically, this task is entirely up to a user, which can sometimes lead to difficulties. An unsuccessful choice may result in the evaluation of the root of the equation not being obtained at all. In addition to the difficulty of choosing an initial approximation, the Newton method has the disadvantage: the method requires the calculation of a derivative of function f for each new approximation of its root. If the function is complex, there may be technical difficulties with differentiating it: for example, additional calculations may be required to reduce the computational efficiency of the algorithm. In the Newton-Rafson method, only one value of the derivative (at the point of initial approximation) is calculated, which reduces the number of calculations. In this case, the rate of convergence decreases to linear [6]. Another related method of the Newton method of finding the root of the equation is the method of secants, which uses the average value of the derivative function (estimated by finite differences). For this method, as for the Newton method, the problem of choosing an initial approximation is relevant. The convergence rate is lower than that of the Newton method (the order of convergence $\alpha=1.618$ ) [7], but it is sufficient to provide 
the method with wide application. The Newton method, the Newton-Rafson method and the secant method are based on the local linearization of the function whose root is to be determined.

One of the simplest methods for finding the roots of nonlinear equations, which is not related to estimating the value of derivatives, is the bisection method (dividing the segment by half) [8]. This method is rather slow, but it always converges with a given accuracy (it guarantees the value of the absolute error of estimating the root of the equation). The half-division method has a linear convergence rate (convergence order $\approx 0.5$ ) [9].

The Muller method [10] uses a quadratic interpolation of the values of the function $f$ whose root is sought, close to the root. The Muller method has a super-linear convergence with an order of convergence of $\alpha \approx 1.8$ [10]. The Muller method can be used to search for multiple roots in which the analyzed function $y=f(x)$ does not intersect the $x$ axis but only touches it [5]: if $x$ is the root of the equation $f(x)=0$, then $f^{\prime}(x)=0$.

The Muller method does not have as fast convergence as the Newton method, but provides a higher guarantee that the iterative process will not disperse: the method never produces root approximations beyond the original interval of its localization. Thus, the method successfully combines the useful properties of methods that approximate the function $f$ by linear approximation (the Newton and the Newton-Rafson methods), but is free from their drawback - the possible divergence. On the other hand, the complexity of the method prevents its widespread use in practical applications.

The methods considered are in principle suitable for their properties (convergence rate, achievable accuracy of the solution, etc.) for most metrological problems, so they are often used in them (except for the Muller method). In the following, questions of computational mathematics related to the application of methods of solving equations in practice will not be considered in this paper.

Indirect measurement equations for most metrological problems, as a rule, have a single root, since the indirectly measured value of a physical quantity has only one true value, uniquely related to the coefficients of the solved equation. If there are several roots (such can be in complex mathematical models of indirect measurements), it is necessary to set such initial conditions (initial approximation, root localization interval) to select one specific root of the equation. Generally used in metrology, the functions $f$, which define the equations of indirect measurements, are sufficiently smooth, monotone curves that carry out an unambiguous mapping. As a rule, when looking for their roots there are no difficulties, except, perhaps, the choice of an initial approximation.
Below we consider in more detail how the methods mentioned above estimate the roots of the equations.

The Bisection Method. Suppose that some function $f(x)$ is continuous and monotonic on a given segment $[a, b]$, and the equation $f(x)=0$ has a unique root on this segment. The latter means that the condition is satisfied $f(a) \cdot f(b) \leq 0$. The essence of the bisection method is that in one step of its application, the segment with the guarantee containing the root is narrowed in half, the sequence of such steps leads to the fact that the segment containing the root becomes as arbitrarily narrow as possible. The midpoint of the segment at each iteration can be considered an approximation of the root value of the equation [11]. At each step, the segment $[a, b]$ is divided by half a point $c=\frac{a+b}{2}$. Then the values of the function $f(a)$ and $f(c)$ at the ents $a$ and $c$ of the left half $[a, c]$ of the original segment $[a, b]$ are compared. If the calculated function values satisfy the condition $f(a) \cdot f(c) \leq 0$, then the left half-section contains the root. Therefore, the right half-segment $[c, b]$ can be excluded from further consideration. If $f(a) \cdot f(c)>0$, then the left half-section $[a, c]$ must be discarded (the root is contained in the right half-section $[c, b])$. Both decisionmaking options at each step of the bisection method are illustrated in Fig. 1.
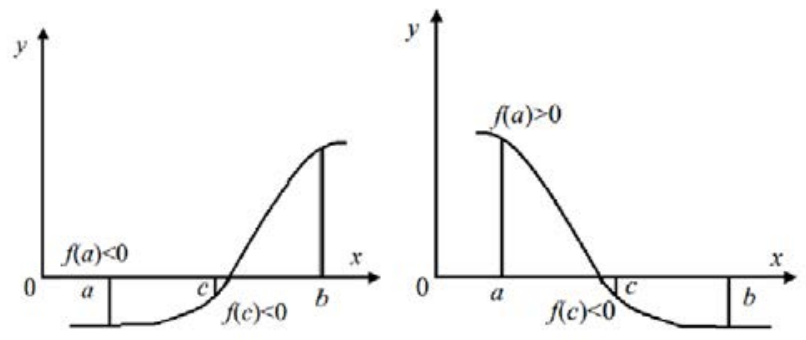

Fig. 1. Bisection method for the function with root in the right part and in the left part of the segment $[a, b]$

After eliminating the right or left half of the current interval of localization of the root of the equation, continue its division in half until the length of the remaining interval $\left[a^{\prime}, b^{\prime}\right]$ becomes less than some given small value $\varepsilon$, i.e. $\left|b^{\prime}-a^{\prime}\right|<2 \cdot \varepsilon$. Then any value from the segment $[a, b]$ can be considered a root with an error of not more than $2 \varepsilon$. Usually, the middle of the segment is taken as the root estimate, then $\varepsilon$ is the limit of the absolute error of the root estimate.

The Newton Method. Suppose that $f(x)=0$ and the initial approximation of $x_{0}$ to its root. In metrological practice, the function $f(x)$ is almost always real. It is necessary to find the real root $x^{\star}$. Suppose that the segment $[a, b]\left(x_{0} \in[a, b]\right)$ contains a single root of the equation, and there are continuous first and second derivatives of $f$ other than zero: $f^{\prime}(x) \neq 0, f^{\prime \prime}(x) \neq 0$. The equation $f(x)=0$ in the neighborhood of $x_{0}$ is replaced approximately by an equation $f\left(x_{0}\right)+f^{\prime}\left(x_{0}\right) \cdot\left(x-x_{0}\right)=0$, the left part of which is the linear part of the expansion 
of the function $f(x)$ into the Taylor series near the point $x_{0}$. From here the following approximations of the root are expressed - the value $x_{1}$. In the next step, the function $f$ is replaced again by a linear term of the Taylor series already constructed near the point $x_{1}$. Thus, the calculation formula for the Newton method for calculating the current approximation for the root of the equation [12] is

$$
x_{k}=x_{k-1}-\frac{f\left(x_{k-1}\right)}{f^{\prime}\left(x_{k-1}\right)}, k=1,2, \ldots
$$

The Newton method has a simple geometric meaning (presented in Fig. 2): $x_{k}$ is the abscissa of the intersection point tangent to the graph of the function $f(x)$ constructed at the point $\left(x_{k-1}, f\left(x_{k-1}\right)\right)$, with the abscissa axis.

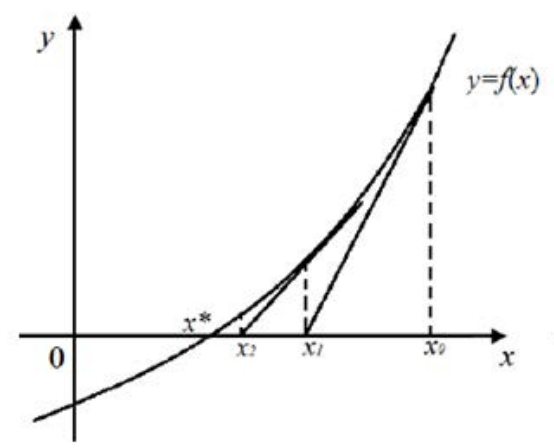

Fig. 2. Illustration of the Newton method

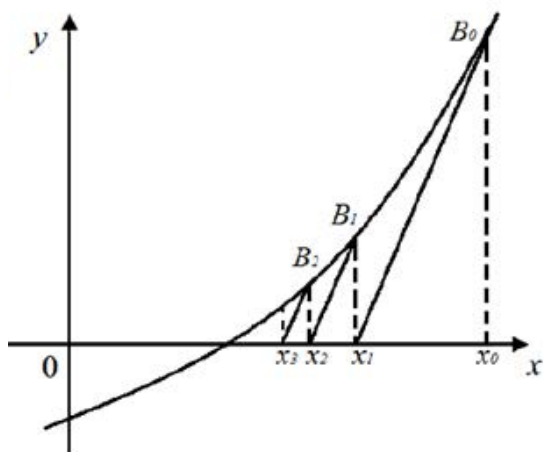

Fig. 3. The geometric meaning of the modified Newton method

The Newton-Rafson Method. The NewtonRafson method is a modified Newton method. The modification is to replace the derivative $\boldsymbol{f}^{\prime}\left(\boldsymbol{x}_{\boldsymbol{k}}\right)$ at the point $x_{k}$ in formula (1) with the derivative $f^{\prime}\left(x_{0}\right)$ at the point $x_{0}$, i.e. we have $f^{\prime}\left(x_{k}\right) \approx f^{\prime}\left(x_{0}\right)$. As a result of this approximation, the following calculated formula [6] is obtained:

$$
\boldsymbol{x}_{\boldsymbol{k}+1}=\boldsymbol{x}_{\boldsymbol{k}}-\frac{\boldsymbol{f}\left(\boldsymbol{x}_{\boldsymbol{k}}\right)}{\boldsymbol{f}^{\prime}\left(\boldsymbol{x}_{0}\right)}, \boldsymbol{k}=0,1,2, \ldots
$$

This method has the following geometric meaning: tangents at points $B_{n}=\mathrm{f}\left(x_{n}\right)$ are replaced by straight lines parallel to tangents to the curve $y=f(x)$ at point

$B_{0}=\mathrm{f}\left(x_{0}\right)$ (illustrated in Fig. 3).

The advantage of this method over the Newton method is that it is not necessary to calculate at each iteration a derivative $f^{\prime}\left(x_{k}\right)$.

The Secant Method. The secant method is also a modification of the Newton method. In this method, an approximate calculation of the derivative $f^{\prime}(x)$ is performed in the neighborhood of the point $\mathrm{xk}$ by the finite difference formula [13]:

$$
f^{\prime}\left(x_{k}\right) \approx \frac{f\left(x_{k}\right)-f\left(x_{k-1}\right)}{x_{k}-x_{k-1}}
$$

Substituting this expression into Newton's formula (1.1), we obtain the calculated formula [11]:

$$
x_{k+1}=x_{k}-\frac{f\left(x_{k}\right)\left(x_{k}-x_{k-1}\right)}{f\left(x_{k}\right)-f\left(x_{k-1}\right)}, k=1,2, \ldots
$$

The geometric interpretation of the secant method is as follows: a secant one drawn through points $\left(x_{0}\right.$, $\left.f\left(x_{0}\right)\right)$ и $\left(x_{1}, f\left(x_{1}\right)\right)$, intersects the abscissa at $x_{2}$, which is determined by formula (4).

To start an iterative process using the secant method, two initial approximations $x_{0}$ and $x_{1}$ must be specified. In practice, usually the zero approximation $x_{0}$ is chosen similarly to the choice of the initial approximation in the Newton method, and a small number is chosen as the point $x_{1} . x_{1}=x_{0} \pm \varepsilon$, where $\varepsilon-$ small number.

The secant method is slightly inferior to the Newton method in convergence rate, but it does not require explicit calculation of the derivative. Therefore, it is especially useful when obtaining an analytical expression for a derivative is difficult or impossible.

The Muller Method. The Muller method is based on the interpolation of the parabola of the values of the studied function over its three points.

The idea of the Muller method is to approximate the replacement of the function $y=f(x)$ by a second-degree interpolation polynomial (parabola) constructed on three points $x_{k-2}, x_{k-1}, x_{k}$, and find the abscissa of the intersection point of this parabola with the $x$-axis, i.e. by solving the quadratic equation. Thus, the Muller method does not use a linear approximation, as in the secant and the Newton methods, but a quadratic one, which complicates the calculations and complicates the search for the root of the equation in algorithmic terms.

The calculated formulas for estimating the root of the equation $f(x)=0$ by the Muller method are the following [8]:

$$
\begin{gathered}
x_{k+1}=x_{k}-\left(x_{k}-x_{k-1}\right)\left(\frac{2 C}{B \pm \sqrt{B^{2}-4 A C}}\right), \\
A=q f\left(x_{k}\right)-q(1+q) f\left(x_{k-1}\right) q^{2} f\left(x_{k-2}\right), \\
B=(2 q+1) f\left(x_{k}\right)-(1+q)^{2} f\left(x_{k-1}\right)+q^{2} f\left(x_{k-2}\right), \\
C=(1+q) f\left(x_{k}\right), \\
q=\frac{x_{k}-x_{k-1}}{x_{k-1}-x_{k-2}} .
\end{gathered}
$$


The sign in front of the root is selected so that the absolute value of the denominator is maximum.

Matlab/Octave packages have developed procedures that implement the following methods for finding the roots of the equations (see Appendix).

The simulation was performed for the equation from the problem of pollution propagation in the external environment [13]: $f(x)=e^{a x}-b x$, $a, b-$ results of direct measurements, $x$ is unknown value (result of indirect measurements). The following values: $a=-0,49, b=2,00$ were chosen as the results of direct measurements. The rule of stopping the iteration process in the form opopme $\left|x_{k+1}-x_{k}\right| \leq \varepsilon$, was also chosen, where the value of $\varepsilon$ is $10^{-10}$. The initial approximations are given by $x_{0}=0, x_{1}=1, x_{2}=0,5$. The interval for the bisection method is $[0,1]$. The sequences of the obtained root approximations, where $n$ is the iteration number and $x_{n}$ is the root approximation value in step $n$.

The solutions obtained by different methods are indicated as follows: 1 is the bisection method, 2 is the Newton method, 3 is the Newton-Rafson method, 4 is the secant method, 5 is the Muller method.

The results of the calculations are presented in Table 1 (exact root value is $x^{\star}=0,409165$ ).

The solutions obtained by different methods are indicated as follows: 1 is the bisection method, 2 is the Newton method, 3 is the Newton-Rafson method, 4 is the secant method, 5 is the Muller method.

The results of the calculations are presented in Table 1 (exact root value is $x^{*}=0,409165$ ).

Table 1

Results obtained

\begin{tabular}{|c|c|c|}
\hline Method & $\begin{array}{c}\text { Number } \\
\text { of iterations }\end{array}$ & $\begin{array}{c}\text { Root } \\
\text { approximation }\end{array}$ \\
\hline the bisection & 34 & 0,409165 \\
\hline the Newton & 4 & 0,409165 \\
\hline the Newton-Rafson & 8 & 0,409165 \\
\hline the secant & 5 & 0,409165 \\
\hline the Muller & 4 & 0,409165 \\
\hline
\end{tabular}

The obtained results show that the bisection method converges for a much larger number of iterations than the other methods (as noted in the review); the Newton method and the Muller method converged for the least number of iterations. From the obtained results we can conclude that the Newton method and the Muller method have the best characteristics (fast convergence). The simulation results are consistent with the theoretical data (from the review) on the convergence rate of the methods.

Conclusions from this study and prospects for further exploration in this direction. The introduction of computer technology into the teaching process in higher education institutions corresponds to the innovative processes that are taking place in
Ukraine today in order to modernize the education system.

The ability to effectively use ICT as a future teacher of mathematics in the professional development process is an urgent problem that is being identified by UNESCO, the European Council and others, both governmental and non-governmental institutions. This is due to the intensification of both school education in general and mathematics education in particular, the ever-increasing potential of computer aids and, at the same time, the lack of effective use of such facilities by teachers in their professional activities.

Therefore, the application of the developed practical skills to gain new practical experience, which will make the mathematics education process as effective and methodically diverse as possible, the ability to analyze their own professional activity in the efficiency of the use of computer technologies of teaching mathematics leads to a conscious need to acquire new knowledge in the field of using ICT in learning math.

On the practical example of the solution of the indirect measurement equations we have developed the techniques for solving the indirect measurement equations, justified from the metrological point of view using the Matlab package. For this purpose, iterative methods for solving the equations known from computational mathematics were supplemented, so that the obtained estimates of the root are accompanied by an estimate of their error caused by the inaccuracy of the coefficients of the equation (direct measurements). In this case, the error estimates are obtained simultaneously with the solution of the equation for any set of initial data, which allows to justify interrupting the iterative procedure in accordance with the accuracy of the initial data, and also leads to a gain at run time.

\section{REFERENCES:}

1. Алєксєєва Г.М. Формування готовності майбутніх соціальних педагогів до застосування комп'ютерних технологій у професійній діяльності. Монограсрія. Бердянськ: БДПУ, 2014.

2. Алєксєєва Г.М. Використання інформаційнокомунікаційних технологій в процесі профресійної підготовки студентів педагогічних вузів. Актуальні питання природничо-математичної освіти. Суми : ВВП «Мрія», 2014.

3. Островский А.М. Решение уравнений и систем уравнений. Москва, 1963.

4. Арушанян И.О. Практикум на ЭВМ Безусловная минимизация фуннций многих переменных. Москва, 2012.

5. Зайцев В.В., Трещев В.М. Численные методы для фризиков. Нелинейные уравнения и оптимизация: учебное пособие. Самара : изд-во «Самарский университет», 2005.

6. Лапчик М.П., Рагулина М.И., Хеннер Е.К. Численные методы. Москва : Академия, 2004. 
7. Амосов А., Дубинский Ю.А., Копченова Н.В. Вычислительные методы для инженеров : Учеб. пособие. Москва : Высш. шк., 1994.

8. Самарский А.А., Гулин А.В. Численные методы : Учеб. пособие для вузов. Москва : Наука. Гл. ред. фриз.-мат. лит., 1989.

9. Волков Е.А. Численные методы. Москва : Наука, 1987.
10. Основы численных методов. Учебное пособие для студентов фракультета фризики. URL: http://physics.herzen.spb.ru/teaching/materials/ gosexam/nonlineareq.pdf.

11. Турчак Л.И. Основы численных методов : Учеб. пособие. Москва : Наука. Гл. ред. фриз.-мат. лит., 1987.

12. Бахвалов Н.С., Жидков Н.П., Кобельков Г.М. Численные методы. Москва : Наука, 2002. 